\title{
On the Effectiveness of Feed-in Tariffs in the Development of Solar Photovoltaics
}

\author{
Elbert Dijkgraaf, * Tom P. van Dorp, ** and Emiel Maasland***
}

\begin{abstract}
Growing concern about climate change and rising prices of fossil fuels has prompted governments to stimulate the development of renewables. The most common instrument is a feed-in tariff (FIT). This paper empirically tests whether or not FIT policies have been effective in encouraging the development of photovoltaic solar (PV), explicitly taking into account the structure and consistency of FITs. Panel data estimations are employed for 30 OECD member countries in the period 1990-2011. We find a positive effect of the presence of a FIT on the development of a country's added yearly capacity of PV per capita. This is in line with the results found in the existing literature. However, our study shows that the literature underestimates the potential impact of FITs, as the effect of a welldesigned FIT is much larger than the average effect of the currently applied FITs. Not only the height of the tariff is important, but also the duration of the contract and the absence/presence of a cap have an impact. We also show that consistency greatly affects the effectiveness of FITs. Consistency is especially important when the tariff of a FIT is low. The total effect of a FIT can be seven times larger if it is well designed. Our results are robust for differences between countries with respect to the availability of other policy instruments, the use of nuclear or hydro power and the level of $\mathrm{CO}_{2}$ emissions.
\end{abstract}

Keywords: Energy policy, Solar photovoltaics, Feed-in tariff, Policy consistency, OECD

https://doi.org/10.5547/01956574.39.1.edij

\section{INTRODUCTION}

Over the past few decades, an increasing number of governments have started to stimulate the development of renewable electricity sources. ${ }^{1}$ Important motivations for doing so have been growing concern about climate change, rising prices of fossil fuels and governments' objectives to reduce dependence on energy imported from abroad. ${ }^{2}$ To date, international agreements on carbon

1. For an empirical study why some countries have been front runners implementing renewable electricity policies while others have been more reluctant, see e.g. Jenner et al. (2012).

2. See for example, Klein et al. (2010) and Marques et al. (2010).

* Corresponding author. Erasmus School of Economics, Erasmus University Rotterdam, and Tinbergen Institute, Burgemeester Oudlaan 50, 3062 PA Rotterdam, The Netherlands. E-mail: dijkgraaf@ese.eur.nl.

** Solarplaza International BV, Conradstraat 38 (D3-135), 3013 AP Rotterdam, The Netherlands.

*** Erasmus School of Economics, Erasmus University Rotterdam, Burgemeester Oudlaan 50, 3062 PA Rotterdam, The Netherlands. E-mail: emaasland@ese.eur.nl.

The Energy Journal, Vol. 39, No. 1. Copyright (C) 2018 by the IAEE. All rights reserved. 
emission reduction and renewable energy targets, such as those included in the Kyoto Protocol, play a key role in the promotion of renewables.

Of the most common sources of renewable electricity-biomass, wind, solar, geothermal and hydropower-solar photovoltaics (PV) has undergone its growth spurt most recently, with a worldwide average yearly growth of $47 \%$ over the last decade. ${ }^{3}$ This development has increasingly resulted in up-scaled manufacturing facilities and technology improvements by R\&D. As both have driven the price of PV-systems down, PV has gradually become a competitive electricity source. At the outset of the development of the PV-industry, important conventional electricity sources, such as nuclear and coal-fired power plants, were able to produce electricity at only a fraction of the cost at which one solar kilowatt-hour $(\mathrm{kWh})$ could be generated. In terms of bridging the competitive gap between conventional and renewable electricity sources, the role of governments has generally been considered crucial. ${ }^{4}$

The USA was the first country in the world to adopt policies in support of PV; the Public Utility Regulatory Policies Act (PURPA), adopted in 1978, included solar in its list of 'qualifying facilities'. Many other governments included smaller incentive programs during the 1980s and early 1990s. In 1991, the Electricity Feed Law (Stromeinspeisungsgesetz) entered into force in Germany. This Feed-in Tariff (FIT) Law introduced the obligation on the part of the large electricity utilities to accept the electricity generated by small renewable electricity producers and to remunerate them for the electricity fed into the grid. PV solar producers received a tariff equal to $90 \%$ of the (average historical) electricity retail price, for an indefinite period. Simultaneously, Germany introduced the, so-called, '1000 Roofs Programme', which involved providing compensation for grid connected PV systems on small roofs with a grant amounting to $70 \%$ of the investment. Japan subsidized PV with its 'Subsidy Programme for Residential PV Systems' in 1994. Japan and Germany were responsible for the bulk of the growth in the global PV-industry. Their combined share of the cumulative installed capacity in the OECD reached $78.5 \%$ at its peak in 2006. ${ }^{5}$ At that time, several other countries in the OECD started to promote PV using policy instruments. Policymakers introduced several combinations of instruments, but the most common instrument was the FIT. FITs differed in their various design features, including tariff amount, contract duration and limitations on available budget or installed capacity. ${ }^{6}$ The tariff amount was not necessarily fixed; it could also gradually decrease over time (through a mechanism called, degression) ${ }^{7}$ or increase (due to inflation indexation). Some countries (e.g. Ireland, Spain and France) indexed tariffs to inflation quite generously, while other countries (e.g. Germany) did not index at all, leaving the tariffs fixed in nominal terms. $^{8}$

In the past few years, uncertainty increased regarding the efficacy of FIT policies in terms of the development of PV. Policymakers also had difficulty finding the optimal structure of a FIT. A suboptimal FIT-structure could be the reason that some countries are lagging behind in the development of PV compared to other countries. In light of this, it is worthwhile to empirically

3. See REN21 (2016) and MIT Energy Initiative (2015).

4. See for example, Green and Yatchew (2012) and Timilsina et al. (2012).

5. See OECD-iLibrary.

6. See for example, Couture et al. (2010) and Klein et al. (2010).

7. The intention behind tariff degression is to avoid unnecessary subsidies due to reductions in technology costs over time. Policymakers typically attempt to maintain the same level of profitability across years. Alizamir et al. (2016), however, show that from a cost-efficiency point of view, maintaining profitability at a constant level is rarely optimal.

8. See for example, Couture and Gagnon (2010). 
analyze the relationship between effectiveness and the structure of a FIT. In addition to FIT-structure, policy consistency also influences the effectiveness of a FIT. ${ }^{9}$ As at the end of the lifespan of a FIT a government can decide whether or not to create a new FIT or one with fewer advantages, investors remain unsure about whether and when to invest if the lifespan is short compared to the economically relevant period of the investment. This is especially the case if a government has a history of policy inconsistency. Policy consistency should therefore also be a vital part of any study of the relationship between FIT policies and the development of PV.

This paper studies whether or not FIT policies have been effective in the development of solar PV in OECD member countries. To the best of our knowledge, this is the first paper that empirically addresses this research question while taking into account both design features and consistency of FIT policies. Jenner et al. (2013), Jenner (2012) and Bolkesjø et al. (2014) are the only three empirical studies that have assessed the effectiveness of FITs in promoting the development of electricity from renewable energy sources, including PV. Jenner et al. (2013) develop an indicator for FIT strength that captures several design features such as tariff size, contract duration and degression rate, as well as electricity price and production cost, to estimate the resulting return on investment (ROI). Using a sample of 26 EU countries between 1992 and 2008, they find that for a $10 \%$ increase in ROI, 3.8\% more PV capacity will be installed on average per year. Their conclusion is that FIT policies stimulated the development of PV in Europe between 1992 and 2008. Jenner (2012), who uses generation in GWh instead of annual solar capacity as a dependent variable, comes to the same conclusion for the period 1990-2010. According to this study, a $1 \%$ increase in ROI increases PV generation by approximately 27 GWh. Bolkesjø et al. (2014) who consider a longer period of time (1990-2012), but only study five European countries (France, Germany, Italy, Spain and the United Kingdom) also show a significant positive impact of FITs on investments in PV capacity. An important shortcoming of these studies is that both the individual design features of a FIT and the price of electricity are not included as separate variables in the regressions. The impact of the individual elements can therefore not be determined. In these studies, the role of policy consistency is not taken into account either. An additional advantage of our study is that, in contrast to Jenner (2012) and Jenner et al. (2013), our data set (comprising the years 1990-2011) spans the entire period in which solar FITs, in particular, were in place (2006-2011).

A fourth related empirical paper is Marques and Fuinhas (2012), which analyzes the impact of policy incentives on the total contribution of renewables to total energy supply by focusing on a panel of 23 European countries in the time span 1990-2007. The results presented in this paper provide empirical support for the notion that public policy measures contribute to the wider use of renewables. In particular, incentive and subsidy policies (including FITs, grants, preferential loans, rebates and third-party financing) and policy processes, i.e. policies and measures that define strategies and outline specific programs to promote specific renewable energy sources in a country, turned out to be effective. Quota obligations, R\&D programs and tradable certificates did not increase the use of renewables in the period under study. As FITs and the development of solar PV are not treated as separate variables in this paper, it is less related to our study than the three empirical papers mentioned above.

The majority of the existing literature is limited to a descriptive approach to analyzing the effectiveness of policy instruments on the development of renewable energy sources. Haas et al.

9. See for example, White et al. (2013), Lüthi (2010), Cory et al. (2009), Owens and Driffill (2008), Van Rooijen and Van Wees (2006), Loiter and Norberg-Bohm (1999), and Gardner and Stern (1996). 
(2011a), who compare quantity-driven instruments (like tenders and Tradable Green Certificates (TGCs) based on quotas ${ }^{10}$ ) and price-driven instruments (like FITs) in European countries, state that FIT policy instruments are more effective than others in the deployment of less mature technologies, like solar PV technology, because they tend to have low administration costs, are relatively easy to implement and are technology focused. ${ }^{11}$ They argue that a well-designed FIT policy leads to the deployment of renewable energy sources in the shortest time and at the lowest cost for society. Also, Gipe (2006), Mendonça (2007), Mendonça et al. (2009), Cory et al. (2009) and Timilsina et al. (2012) show qualitatively that FITs are a major driver of the development of most solar PV markets. Bürer and Wüstenhagen (2009) add that investors from European and North American venture capital and private equity funds prefer FITs over other policy instruments. ${ }^{12}$ Grau (2014), who analyzes the relative merits of using FITs and tenders to support different scales of PV projects, argues, on the basis of an analytical model, that responsive FIT schemes with frequent tariff adjustments are able to reach deployment targets more effectively for small PV systems than for largescale plants (with longer project durations). Tenders with set quantities and appropriate incentives to realize successful applications might—according to this study—be a better mechanism to apply for large-scale plants: the long-term contract may reduce the investor's risk inherent to flexible FITs. Grau admits, however, that project implementation success rates largely differ across countries with tenders. The dominant view in the literature is that price-based FIT policies are superior to quantity-based TGC/RPS approaches. Schmalensee (2012) contests this view. According to him, this view is primarily based on experiences in the EU, where FIT policies (in Spain and Germany, for example) outperformed TGC policies (in the United Kingdom, for example), and less on experiences in the USA, where the RPS program (in Texas, for example) has turned out to be successful in practice. Schmalensee also argues that FIT measures just shift market risk from investors in renewable generation to other market actors and those who pay the subsidies and thus do not necessarily reduce the risk to society as a whole. Using a very stylized, long-run model of a large electric power system with fixed total load, Schmalensee shows that the long-run societal risk may actually be higher under a FIT than under a comparable RPS.

Based on a historical review of promotion strategies for electricity from renewable energy sources in EU countries, Haas et al. (2011b) conclude that it is not all about the common question of which instrument is best, but more about the design criteria of implemented RES-E support schemes. ${ }^{13}$ The support level is an obvious criterion. The qualitative literature is generally in agreement, though, that other factors such as policy stability, long-term certainty, the availability of disposable income, the permitting and land-access process, the rules and procedures governing grid access and interconnection often play an equally, if not more, important role. For example, Resch et al. (2007) argue that a long-term and stable policy environment is the key criterion for the success of developing RES-E markets. To illustrate this argument, they show that Spain and Germany (two countries with high investment security and low administrative barriers) were quite effective in developing onshore wind electricity in spite of the fact that the FIT level was not particularly high in these two countries as compared to other countries. In contrast, France (a country with high

10. In the USA and Japan, these TGC systems are better known as Renewable Portfolio Standards (RPS).

11. Also Menanteau et al. (2003) show that, in terms of installed wind power capacity, price-driven instruments have produced far better results than quantity-driven instruments.

12. For solar PV, $69 \%$ of the investors rated Germany as the most favorable country (followed by Japan, Spain and the USA).

13. In line with this conclusion, Shrimali et al. (2015), who econometrically analyze the effectiveness of RPS policies in the USA, show that modeling of specific RPS design features is essential, as not doing so may lead to misperceptions. 
administrative barriers), was not effective at all, even in the context of a stable policy environment combined with reasonably high FITs. Also Zhang (2013) finds that higher subsidies have not necessarily yielded greater levels of renewable installation. The study also highlights the fact that the design of the overall electricity market matters: a competitive market tends to be more conducive to renewable deployment. Lüthi and Wüstenhagen (2012) confirm the importance of 'non-economic' barriers on the basis of an ex-ante analysis of the stated preferences of key decision-makers in the solar market. In the present study, however, we focus exclusively on economic instruments and leave it to future research to include more of these variables, as we have no data to test the influence of these variables at present.

The remainder of this paper is organized as follows. Section 2 specifies the structure of the models. Section 3 describes the data set. Section 4 presents the results and provides an interpretation. Section 5 concludes.

\section{THE MODELS}

In order to investigate the impact of FITs on the development of PV, a series of linear models are investigated. The specification of the models is as follows:

$$
\mathrm{PV}_{\mathrm{it}}=\beta_{1}+\beta_{2 \mathrm{jt}} \mathrm{FIT}_{\mathrm{it}}+\beta_{3 \mathrm{kt}} \mathrm{Z}_{\mathrm{it}}+\beta_{4 \mathrm{t}} \mathrm{T}_{\mathrm{t}}+\eta_{\mathrm{i}}+\varepsilon_{\mathrm{it}}
$$

where $\mathrm{PV}_{\text {it }}$ is a measure of the use of PV in country $i$ in year $t$, FIT $_{\text {it }}$ is a vector of FIT policy variables, $Z_{i t}$ is a vector of country and time-specific characteristics, $T_{t}$ is a time trend, $\eta_{i}$ is country fixed effects, $\varepsilon_{\mathrm{it}}$ is the error term and $\beta$ s are parameters.

PV is measured as added yearly capacity per capita (ADDCAPC). Capacity is normalized by population to prevent heteroscedasticity. This measure is chosen as indicator for estimating the impact of a FIT because FIT policy subsidizes new capacity. An indicator like the share of PV in total production would be a much less adequate indicator to use because the PV share in year $t$ will depend most strongly on the PV share in year $t-1$, less so on the FIT policy characteristics in year $t$.

$\mathrm{Z}_{\mathrm{it}}$ includes country and year-specific cost differences for PV related to differences in solar irradiation (Cost), wealth (GDP per capita), trade openness (OPENNESS), population density (POPDENS), import of energy (ENERGYIMPORT), capacity of the electricity production plants (ELECCAPACITY) and price of household electricity (ELECPRICEHH). Cost is measured as the average cost of generating one solar MWh (taking solar irradiation and PV-system price into account). Wealth (GDPcap) is included to account for the possibility that richer countries invest more in PV; we also include GDPcap ${ }^{2}$ to enable the relationship to be non-linear analogous to the Environmental Kuznets Curve. ${ }^{14}$ OPENNESS, measured as the percentage of export and import of GDP, is included as more open countries might import new PV technologies more easily and profit more from PV export, making national investments more profitable. POPDENS, measured as the number of inhabitants per square kilometer, is included as PV is a land intensive energy technology. ENERGYIMPORT, measured as share of total energy, is included as a higher share might create more incentives to decrease this share by investing in PV. ELECCAPACITY is included as a higher capacity results in more replacement investments and thus a greater likelihood of investment in PV. ELECPRICEHH is included as a higher price makes it more likely that the business case for PV 
becomes profitable. We do not include industrial electricity prices because this would cause collinearity and would not contribute to the explanatory power of the model. We have chosen to include the household electricity price variable because it is less correlated with the other variables in the model. ${ }^{15}$

We include a time trend $\left(T_{t}\right)$ to correct for autonomous developments, like technological developments. Country fixed effects $\left(\eta_{\mathrm{i}}\right)$ are included to correct for unobserved differences between countries.

We estimate three models. In the first model, we treated FIT $_{\text {it }}$ as a FIT dummy, whose value is one if a FIT is present in a particular country-year and zero otherwise. This provides us with the average effect of the FITs present in our sample. We expect a positive effect, as a FIT makes PV more attractive to producers. In the second model, we replace the FIT dummy with three FIT design features (Tariff, Duration and Cap) to test whether or not FIT design matters. Tariff represents the subsidy per unit of electricity produced. Duration measures the length of the contract between the government and the producer in years. Cap is a dummy variable which is coded as one (and zero otherwise) if there is a pre-defined maximum on either the budget or the installed capacity during a fixed period of time for PV. We use a binary valuation for this specific design characteristic since-due to the high variability in caps-it is difficult to classify the caps and because there are relatively few FIT policies that include a cap. For Tariff and Duration, we expect a positive effect on $\mathrm{PV}$, as a higher tariff and a longer contract period make PV more attractive to the producer. For Cap, we expect a negative effect, as a cap can cause uncertainty amongst potential investors, as they are no longer sure whether pre-investment costs can be recouped. In the third model, we test the influence of FIT policy consistency on PV. We measure consistency using the standard deviation of Tariff, Duration and Cap based on the last five observations. ${ }^{16}$ Given the level of the tariff, contract duration and the cap, we expect that more variability has a negative influence on PV, as it increases uncertainty about the FIT. If potential investors gain confidence in the continuity of a policy, the effectiveness of a FIT is expected to increase. So, the more constant the tariffs, contract duration and the cap are over the years, the higher the level of consistency and the greater the expected effectiveness.

We perform four sensitivity analyses. ${ }^{17}$ In the first sensitivity analysis, we include nonFIT policy instruments. The specification of the model is then as follows:

$$
\mathrm{PV}_{\mathrm{it}}=\beta_{1}+\beta_{2 \mathrm{jt}} \mathrm{FIT}_{\mathrm{it}}+\beta_{3 \mathrm{jt}} \mathrm{P}_{\mathrm{it}}+\beta_{4 \mathrm{kt}} \mathrm{Z}_{\mathrm{it}}+\beta_{5 \mathrm{t}} \mathrm{T}_{\mathrm{t}}+\eta_{\mathrm{i}}+\varepsilon_{\mathrm{it}}
$$

where $\mathrm{P}_{\mathrm{it}}$ is a vector of non-FIT policy variables: RD\&D budgets for investments in the PV sector per capita (RDDBUDGET), investment and tax incentives (POLINVEST), net metering policies (POLNETMET) and calls for tender (POLTEN). As these instruments are used less often, limiting the number of possible observations and are measured in a rough manner (generally based only on a simple count of available instruments), we did not include these variables in our base models. For RDDBUDGET, the expected sign of the estimated coefficient is unclear. In the long term, we expect a positive sign because more RD\&D might lead to a bigger PV industry, which would

15. When an observation for the household electricity price variable failed, we used the yearly growth rate of the industrial electricity price (if available) to calculate a proxy.

16. We therefore have the standard deviation for all three design features per country per year. We assume the standard deviations in 1986, 1987, 1988, 1989 (the years prior to the start of our dataset) to be 0 .

17. For these analyses, we use the third model, as this model turns out to be the best model. 
produce greater added capacity for PV. However, in the short term, more RD\&D subsidies have the potential to crowd out the budget for PV implementation if the focus is more on innovation than on applying existing technologies. For the other three instruments the expected sign is positive.

In the second sensitivity analysis, we test whether or not there is an extra effect for countries with a high level of electricity production on the basis of nuclear and hydro sources. It could be argued that countries that are more reliant on nuclear/hydro sources have less incentive to produce more PV, as the use of nuclear/hydro sources already saves in terms of $\mathrm{CO}_{2}$ emissions. We include a dummy (Nuclear/Hydro) variable whose value is one (and zero otherwise) if the share of electricity production using nuclear and hydro sources in 2011 in a country is above the average for all countries (34\%). This means that we have a dummy with value of one for Austria, Belgium, Czech Republic, Finland, France, Hungary, New Zealand, Norway, Slovakia, Slovenia, Sweden and Switzerland.

In the third sensitivity analysis, we elaborate on this argument by discriminating between countries with a relatively high and relatively low levels of per capita $\mathrm{CO}_{2}$ emissions. We expect that countries with a relatively high level of $\mathrm{CO}_{2}$ emissions have a greater incentive to increase their PV capacity. We include a dummy $\left(\mathrm{CO}_{2}\right.$ above) which is coded as one for all years for a country if $\mathrm{CO}_{2}$ emissions in 2011 were higher than the average of that of all countries (and zero otherwise). This means that we have a dummy with a value of one for Belgium, Czech Republic, Denmark, Estonia, Finland, Germany, Greece, Ireland, Japan, Korea, Luxembourg, Netherlands, Norway, Poland and Slovenia.

In the fourth sensitivity analysis, we test whether differences exist between countries with a relatively low and relatively high levels of tariff and tariff consistency. It could be the case, for instance, that the effect of a low, but consistent tariff (Low tariff, Low std. dev.) is larger than the effect of a high, but inconsistent tariff (High tariff, High std. dev.). On the other hand, if producers face a short time horizon, the height of the tariff might be more important than its consistency. We therefore include four variables combining low and high tariffs and their standard deviation. Countries with a low tariff and high consistency (Low tariff, Low std. dev.), on average, are Estonia, Israel, Netherlands, Portugal and Slovakia. Countries with a low tariff and low consistency (Low tariff, High std. dev.), on average, are Denmark, Hungary, Japan, Luxembourg, Turkey and United Kingdom. Countries with a high tariff and high consistency (High tariff, Low std. dev.), on average, are Austria, Czech Republic, Germany, Korea, Slovenia and Spain. Countries with a high tariff and low consistency (High tariff, High std. dev.), on average, are Belgium, France, Greece, Italy and Switzerland.

\section{DESCRIPTION OF THE DATA}

Yearly data were collected for 30 OECD member countries over the period 1990-2011, which amounts to 660 observations. ${ }^{18}$ Four OECD member countries are not included in our panel: Iceland, Australia, Canada and the USA. Iceland is not included because no data was available on electricity prices. Australia, Canada and the USA are all excluded because their electricity markets are divided into regions or states/provinces with their own, individual, policies and because consistent data are not available for a sufficient number of states/provinces per country. In Canada, for example, only Ontario, New Brunswick, Nova Scotia and British Columbia have seen some variant of a FIT in recent years.

18. The list of OECD member countries can be found here: http://www.oecd.org/about/membersandpartners/. 
Table 1: Descriptive Statistics

\begin{tabular}{lrrrr}
\hline & Mean & Std. dev. & Minimum & Maximum \\
\hline ADDCAPC & 2.05 & 10.73 & 0.00 & 153.09 \\
Fit dummy & 0.20 & 0.40 & 0.00 & 1.00 \\
Tariff & 1.83 & 4.29 & 0.00 & 21.38 \\
一Std. dev. & 0.65 & 1.68 & 0.00 & 10.80 \\
Duration & 3.35 & 7.05 & 0.00 & 25.00 \\
一Std. dev. & 1.10 & 2.93 & 0.00 & 13.69 \\
Cap (dummy) & 0.05 & 0.22 & 0.00 & 1.00 \\
-Std. dev. & 0.19 & 1.18 & 0.00 & 19.09 \\
Nuclear/Hydro & 0.40 & 0.49 & 0.00 & 1.00 \\
CO above & 0.50 & 0.50 & 0.00 & 1.00 \\
Low tariff, Low std. dev. & 0.05 & 0.22 & 0.00 & 1.00 \\
Low tariff, High std. dev. & 0.02 & 0.15 & 0.00 & 1.00 \\
High tariff, Low std. dev. & 0.08 & 0.26 & 0.00 & 1.00 \\
High tariff, High std. dev. & 0.05 & 0.21 & 0.00 & 1.00 \\
RDDBUDGET & 0.32 & 0.64 & 0.00 & 5.20 \\
POLINVEST & 0.29 & 0.45 & 0.00 & 1.00 \\
POLNETMET & 0.06 & 0.24 & 0.00 & 1.00 \\
POLTEN & 0.01 & 0.09 & 0.00 & 1.00 \\
Cost & 189.47 & 85.47 & 32.47 & 488.81 \\
GDPcap & 18.20 & 11.46 & 1.65 & 56.39 \\
OPENNESS & 87.66 & 48.44 & 15.92 & 319.55 \\
POPDENS & 149.05 & 125.74 & 13.09 & 511.37 \\
ENERGYIMPORT & 25.90 & 135.74 & -842.00 & 99.00 \\
ELECCAPACITY & 1.65 & 1.22 & 0.00 & 7.17 \\
ELECPRICEHH & 137.46 & 64.38 & 10.32 & 409.17 \\
\hline
\end{tabular}

The data were obtained in large part from The World Bank, OECD-iLibrary and IEA databases. A list of all variables including their definition, units and data source is provided in the appendix (see Appendix Table A.1). Appendix Table A.2 includes the internet location of the data sources.

When no data on a policy variable was available for a specific country and the added capacity of PV was zero or very close to zero, we assumed that no policy had been in place in this specific country. For variables that had missing country-year observations, we used the average growth rate of five consecutive years in the direct past or future of the failing data point to calculate a proxy.

Descriptive statistics are shown in Table 1. Figure 1 provides an overview of the development of the average added capacity in our dataset and the number of countries with a FIT in place. The figure clearly shows that added capacity grew strongly in the last few years of our dataset. PV increased most significantly in a few forerunner countries, like Germany, Italy and Spain.

Out of the 30 OECD member countries included in this study, 22 have implemented a FIT (countries without a FIT are Chile, Finland, Ireland, Mexico, New Zealand, Norway, Poland and Sweden). For the whole sample, $20 \%$ of the observations have a FIT in place. In the last decade of our data-period (2002-2011), 43\% of the observations include a FIT policy.

Table 2 shows all Tariff observations per country over the years included in this study. This table makes it clear that levels differ substantially. In 2011, the United Kingdom had the highest tariff and Estonia the lowest. Furthermore, the time patterns also differ. Some countries show an increasing tariff in most years, whereas others show a decreasing tariff (e.g. Korea). Still others even reveal an increase in the tariff at first and a decrease later on (e.g. Belgium). It is also 
Figure 1: Average ADDCAPC and Number of Countries with FIT

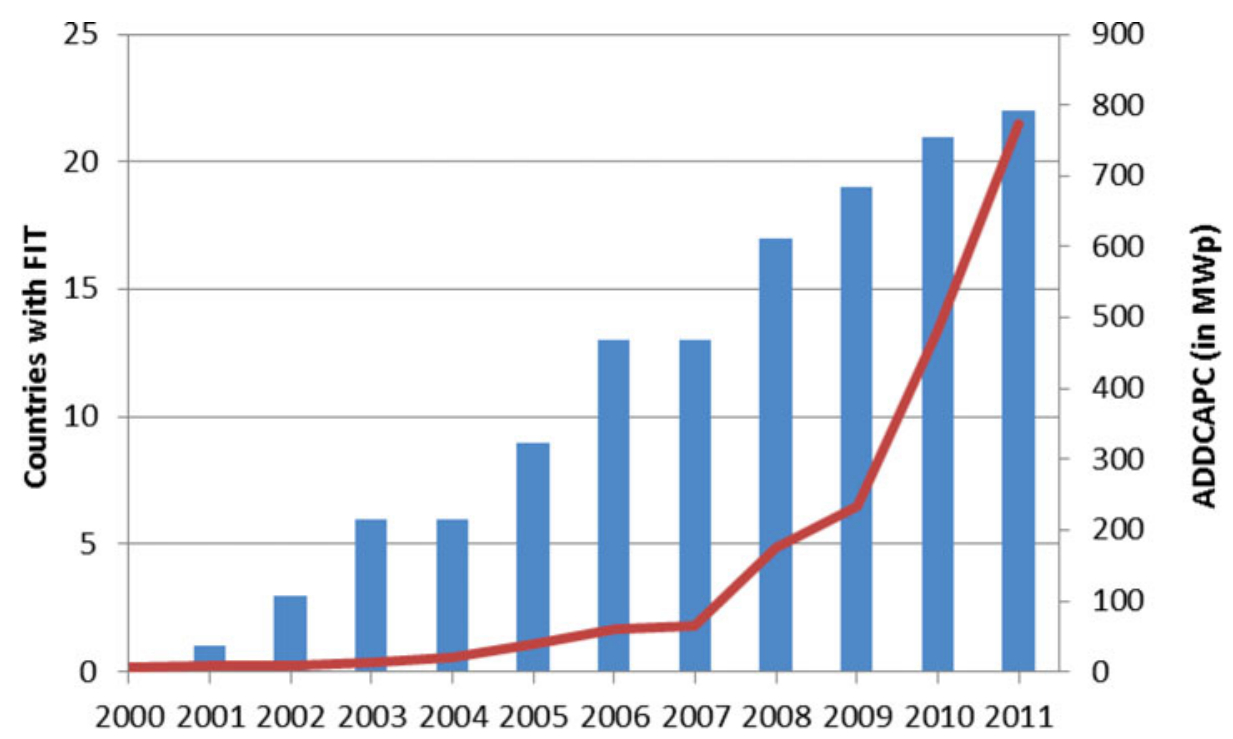

Countries with FIT ADDCAPC (in MWp)

Table 2: Tariff in US\$ per MWh

\begin{tabular}{|c|c|c|c|c|c|c|c|c|c|c|c|}
\hline & 2001 & 2002 & 2003 & 2004 & 2005 & 2006 & 2007 & 2008 & 2009 & 2010 & 2011 \\
\hline Austria & & 12.9 & 12.9 & 12.9 & 12.9 & 9.8 & 9.2 & 9.1 & 9.1 & 7.9 & 7.9 \\
\hline Belgium & & & & & 6.0 & 18.1 & 18.1 & 18.1 & 18.1 & 16.7 & 11.8 \\
\hline Czech Republic & & 6.7 & 6.7 & 6.7 & 6.7 & 15.8 & 15.8 & 15.8 & 17.7 & 17.4 & 9.1 \\
\hline Denmark & & & & & & & & & 2.6 & 2.6 & 2.6 \\
\hline Estonia & & & 2.0 & 2.0 & 2.0 & 2.0 & 2.8 & 2.8 & 2.8 & 2.1 & 2.1 \\
\hline France & & & & & & 12.2 & 12.2 & 12.2 & 13.5 & 11.9 & 9.2 \\
\hline Germany & 20.2 & 19.2 & 18.2 & 21.4 & 20.3 & 19.3 & 18.2 & 17.3 & 15.4 & 13.0 & 10.3 \\
\hline Greece & & & & & & 8.2 & 8.2 & 8.2 & 9.1 & 9.1 & 8.8 \\
\hline Hungary & & & & & & & & & & 3.2 & 3.1 \\
\hline Israel & & & & & & & & 3.8 & 5.4 & 6.0 & 5.9 \\
\hline Italy & & & & & 9.2 & 9.2 & 9.2 & 10.9 & 10.9 & 10.9 & 9.4 \\
\hline Japan & & & & & & & & & 9.3 & 9.3 & 11.9 \\
\hline Korea & & & & & & 15.3 & 14.4 & 11.5 & 8.3 & 8.4 & 8.3 \\
\hline Luxembourg & & & & & & & & 1.1 & 10.0 & 9.7 & 9.3 \\
\hline Netherlands & & & 1.8 & 2.1 & 2.5 & & & 4.4 & 4.1 & 3.7 & 2.3 \\
\hline Portugal & & & 5.3 & 6.7 & 7.7 & 6.1 & 6.1 & 6.4 & 6.4 & 6.4 & 6.4 \\
\hline Slovakia & & & & & & 5.3 & 5.8 & 6.8 & 6.8 & 10.5 & 9.4 \\
\hline Slovenia & & & & & & 8.2 & 8.2 & 8.2 & 11.9 & 11.1 & 9.5 \\
\hline Spain & & & & & 10.5 & 10.5 & 10.8 & 10.8 & 8.2 & 8.2 & 4.3 \\
\hline Switzerland & & & & & & & & 8.8 & 9.0 & 8.0 & 10.1 \\
\hline Turkey & & & & & & & & & & & 2.6 \\
\hline United Kingdom & & & & & & & & & & 14.9 & 15.3 \\
\hline
\end{tabular}

clear that in 2011, all countries faced a decreasing tariff, as decreasing costs as a result of innovation probably necessitated less subsidy.

The average contract duration is 3.4 years, according to Table 1 . However, this also includes the observations of countries without a FIT policy. In 2011, contract duration varied between 
Table 3: Estimation Results for Added Capacity

\begin{tabular}{|c|c|c|c|}
\hline & FIT dummy & FIT features & FIT consistency \\
\hline FIT dummy & $\begin{array}{l}5.486^{* *} \\
(1.345)\end{array}$ & - & - \\
\hline Tariff & - & $\begin{array}{l}0.588 * * \\
(0.202)\end{array}$ & $\begin{array}{l}0.908 * * \\
(0.304)\end{array}$ \\
\hline —Std. dev. & & - & $\begin{array}{r}-1.399 * \\
(0.656)\end{array}$ \\
\hline Duration & - & $\begin{array}{c}0.256 \\
(0.136)\end{array}$ & $\begin{array}{l}0.722 * * \\
(0.181)\end{array}$ \\
\hline 一Std. dev. & & - & $\begin{array}{l}-1.104^{* *} \\
(0.327)\end{array}$ \\
\hline Cap (dummy) & - & $\begin{array}{c}-11.163 * * \\
(2.169)\end{array}$ & $\begin{array}{c}-10.222 * * \\
(2.261)\end{array}$ \\
\hline 一Std. dev. & & - & $\begin{array}{c}0.804 \\
(0.416)\end{array}$ \\
\hline Cost & $-0.065^{* *}$ & $-0.061 * *$ & $-0.053 * *$ \\
\hline GDPcap & $-2.567 * *$ & $-2.391 * *$ & $-1.811 * *$ \\
\hline GDPcap $^{2}$ & $0.024 * *$ & $0.022 * *$ & $0.018^{* *}$ \\
\hline OPENNESS & -0.001 & -0.006 & 0.004 \\
\hline POPDENS & -0.004 & 0.038 & 0.045 \\
\hline ENERGYIMPORT & -0.002 & -0.006 & 0.004 \\
\hline ELECCAPACITY & $15.734 * *$ & $17.579 * *$ & $11.630 * *$ \\
\hline ELECPRICEHH & $0.049 * *$ & $0.043 * *$ & $0.035^{* *}$ \\
\hline TREND & $-0.525^{*}$ & $-0.590^{*}$ & $-0.583^{*}$ \\
\hline Constant & $22.758 *$ & 12.068 & 10.096 \\
\hline Observations & 660 & 660 & 660 \\
\hline $\mathrm{R}^{2}$ & 0.21 & 0.27 & 0.35 \\
\hline
\end{tabular}

Notes: * Significant at the $5 \%$ level; ** significant at the $1 \%$ level. Standard errors are in parentheses.

10 and 25 years for countries with a FIT in our sample. Of all observations with a FIT policy, 25\% have a cap on budget or maximum installed capacity. In 2011, Israel, Korea, Portugal, Spain, Switzerland and Turkey had caps.

\section{RESULTS}

This section provides a discussion of the empirical results. In Section 4.1, we discuss the effectiveness of the FIT policy, its dependence upon the three FIT design features and the impact of the consistency of FITs. In Section 4.2, we present the results of the four sensitivity analyses discussed in Section 2.

\subsection{Effectiveness of FIT}

Table 3 presents the estimation results of the three models..$^{19}$ If the FIT is measured by a FIT dummy (coded as one if a FIT is present) we find an average effect of 5.5 added watts per

19. These models were tested to determine whether or not fixed effects should be included. F-tests showed that fixed effects should indeed be included in all of these models.

Copyright (C) 2018 by the IAEE. All rights reserved. 
Table 4: Marginal Effects Estimation Results Table 3

\begin{tabular}{lrr}
\hline Relevant descriptive statistics for calculation marginal effects & Average & Max \\
\hline Added capacity & 5.1 & 153.1 \\
Tariff & 9.3 & 21.4 \\
- Std. dev. & 3.3 & 10.8 \\
Duration & 17.0 & 25.0 \\
- Std. dev. & 7.7 & 13.7 \\
Cap (dummy) & - & 1.0 \\
- Std. dev. & 2.8 & 19.1 \\
\hline Marginal effects in Wp per inhabitant Model: FIT features & Average & Max \\
\hline Tariff & 5.5 & 12.6 \\
Duration & - & - \\
Cap (dummy) & - & -11.2 \\
\hline Marginal effects in Wp per inhabitant Model: FIT consistency & Average & Max \\
\hline Tariff & 8.5 & 19.4 \\
- Std. dev. & -4.6 & -15.1 \\
Duration & 12.3 & 18.1 \\
- Std. dev. & -8.5 & -15.1 \\
Cap (dummy) & - & -10.2 \\
一 Std. dev. & - & - \\
\hline
\end{tabular}

Note: Marginal effects are only calculated if coefficients are significant at $5 \%$ or $1 \%$.

inhabitant. As the average added Watt for the sample is 5.1 (see Table 4 for the relevant descriptive statistics), this effect is substantial.

The second model includes the three FIT design features. Tariff and Cap have a significant effect, positive for Tariff and negative for Cap. Table 4 shows that the effect of Tariff is up to 12.6 added watts per inhabitant ${ }^{20}$, which is more than twice the average effect in the FIT dummy estimation. If a cap is in place, the effect decreases by 11.2 watts per inhabitant, on average. The coefficient for Duration is not significant in this estimation.

The third model also includes the consistency variables (the standard deviation of Tariff, Duration and Cap). Now, all coefficients of the FIT variables are significant, except for the standard deviation of Cap. The maximum effect of Tariff increases further to 19.4, 3.5 times the average FIT dummy effect. Combined with a maximum duration, the effect of the FIT (37.5) is even almost seven times as large. If the FIT is combined with a cap, the effect of the FIT decreases on average by 10.2 watts per inhabitant. At the maximum level of the standard deviation, the negative effect of changes in the features is 15.1 watts per inhabitant for both Tariff and Duration. The combined effect is thus -30.2 watts per inhabitant.

On the basis of these results, we conclude that FIT design features are quite important. While, in general, the focus is on the tariff, our results show that the duration of the contract, the presence of a cap and policy consistency also have a significant and large impact on the effectiveness of the FIT. Literature that focuses on FITs without discriminating between FIT design features thus underestimates the potential impact of FITs. This also means that the FIT consistency model is our preferred model. We use this model for the sensitivity analyses presented in Section 4.2. 
The coefficient for Cost is significant and negative; cost reductions thus lead to more installed capacity. Cost reductions have been large in the PV industry. In our dataset, the average cost decreased from 334 US\$ in 1990 per MWh to 57 in 2011. If this decrease is multiplied by the estimated coefficient (based on the third model), the effect is 14.7 watts of added capacity per inhabitant $((57-334) * 0.053)$. Based on the first model, it is as high as 18.0 watts $((57-334) * 0.065)$.

The coefficients for GDPcap and GDPcap ${ }^{2}$ imply a non-linear relationship between GDPcap and added capacity of PV. The effect of GDP growth is negative until a level of 50,000 US\$ per inhabitant (based on the third model) is reached and then becomes positive above that level. This non-linear relationship is somewhat surprising, as our expectation was that economic growth would result in more PV. The effect is, however, very small. For the Netherlands, for example, the average effect per year is only $0.5 \mathrm{Wp}$ of added capacity less per inhabitant, while the added capacity in 2011 is $3.4 \mathrm{Wp}$ per capita. Trade openness of a country, population density and energy import have no influence on added capacity of PV. For the electricity capacity and the price of electricity, we find a positive effect. This is in line with our expectations (see Section 2). With a high electricity capacity, more new investments are needed, which creates space for choosing PV. A higher electricity price clearly paves the way for relatively expensive solutions, like PV, as the business case for PV will be positive more often.

\subsection{Sensitivity Analyses}

In Section 4.1, we have shown that the FIT is effective in stimulating the production capacity of PV and that all FIT design features are important to increasing the effectiveness of the FIT. In this section, we report the results of the robustness checks.

First, we estimate the effect of a FIT by including variables for other policy instruments (RD\&D budgets per capita for investments in the PV sector, investment and tax incentives, net metering policies, calls for tender) in the regression model. Including these four policy instruments does not influence our main conclusions presented in Section 4.1. The results for the FIT design features are about equal (see Table 5). The effects of three of the four added instruments are insignificant. Only the RD\&D budget has a significant and negative influence. This is in line with the effect we forecasted for the short term: increased budget for RD\&D crowds out budget for PV implementation.

Second, using a dummy variable for countries with an above-average share of nuclear and hydro power electricity, we tested whether or not availability of nuclear and hydro power drives our results. Table 5 shows that this particular difference between the countries is not driving the results for Tariff and Duration. It does, however, drive our results for Cap; the coefficient is significantly different from zero for countries with an above-average share of nuclear and hydro production. For these countries, the negative effect of a cap disappears almost completely (-0.2). Thus, it is only for countries with a below-average share of nuclear and hydro production that we find a strong negative cap effect (-15.1). In sum, we find no evidence of our prior expectation that countries with greater access to nuclear and hydro power have less incentive to invest in PV. Or, to be more precise, we find no evidence that policies are less effective in these countries.

Third, we tested whether or not a country's $\mathrm{CO}_{2}$-emission level per capita affects our results. Table 5 shows that none of the ' $\mathrm{CO}_{2}$ above' dummies is significant. Therefore, $\mathrm{CO}_{2}$-emission levels have no significant impact on the estimated coefficients in the base model (FIT consistency model in Table 3).

Fourth, we tested whether countries with particularly high or low tariffs and tariff consistency have affected our results. In Section 2, we discussed the creation of four dummies: (Low 
Table 5: Sensitivity Analyses for Added Capacity

\begin{tabular}{|c|c|c|c|c|}
\hline & Other instruments & Nuclear/Hydro & $\mathrm{CO}_{2}$ above & Choice \\
\hline Tariff & $\begin{array}{l}0.839 * * \\
(0.304)\end{array}$ & $\begin{array}{c}0.668^{*} \\
(0.329)\end{array}$ & $\begin{array}{c}1.258^{*} \\
(0.484)\end{array}$ & $\begin{array}{c}0.793^{*} \\
(0.317)\end{array}$ \\
\hline -Std. dev. & $\begin{array}{r}-1.339 * \\
(0.659)\end{array}$ & $\begin{array}{r}-1.611^{*} \\
(0.659)\end{array}$ & $\begin{array}{r}-1.477^{*} \\
(0.662)\end{array}$ & $\begin{array}{r}-1.331^{*} \\
(0.661)\end{array}$ \\
\hline —Nuclear/Hydro & - & $\begin{array}{c}0.600 \\
(0.407)\end{array}$ & - & - \\
\hline$-\mathrm{CO}_{2}$ above & - & - & $\begin{array}{r}-0.386 \\
(0.468)\end{array}$ & - \\
\hline —Low tariff, Low std. dev. & - & - & - & $\begin{array}{c}-8.266^{*} \\
(4.169)\end{array}$ \\
\hline —Low tariff, High std. dev. & - & - & 一 & $\begin{array}{r}-10.302 * \\
(4.918)\end{array}$ \\
\hline —High tariff, Low std. dev. & 一 & - & - & $\begin{array}{r}-5.043 \\
(5.509)\end{array}$ \\
\hline —High tariff, High std. dev. & - & - & - & $\begin{array}{c}-2.476 \\
(5.884)\end{array}$ \\
\hline Duration & $\begin{array}{l}0.745^{* *} \\
(0.181)\end{array}$ & $\begin{array}{l}0.884 * * \\
(0.192)\end{array}$ & $\begin{array}{c}0.653^{*} \\
(0.262)\end{array}$ & $\begin{array}{l}1.044 * * \\
(0.300)\end{array}$ \\
\hline —Std. dev. & $\begin{array}{c}-1.153^{* *} \\
(0.331)\end{array}$ & $\begin{array}{c}-1.074 * * \\
(0.332)\end{array}$ & $\begin{array}{c}-1.100^{* *} \\
(0.329)\end{array}$ & $\begin{array}{c}-1.052^{* *} \\
(0.332)\end{array}$ \\
\hline —Nuclear/Hydro & - & $\begin{array}{c}-0.404 \\
(0.261)\end{array}$ & - & - \\
\hline$-\mathrm{CO}_{2}$ above & - & - & $\begin{array}{c}0.042 \\
(0.271)\end{array}$ & - \\
\hline Cap (dummy) & $\begin{array}{c}-10.300 * * \\
(2.269)\end{array}$ & $\begin{array}{c}-15.052 * * \\
(2.667)\end{array}$ & $\begin{array}{c}-11.953 * * \\
(2.679)\end{array}$ & $\begin{array}{c}-10.413^{* *} \\
(2.279)\end{array}$ \\
\hline —Std. dev. & $\begin{array}{c}0.922 * \\
(0.422)\end{array}$ & $\begin{array}{c}0.953 * \\
(0.416)\end{array}$ & $\begin{array}{c}0.832 \\
(0.428)\end{array}$ & $\begin{array}{l}0.832 * * \\
(0.423)\end{array}$ \\
\hline —Nuclear/Hydro & - & $\begin{array}{l}14.863 * * \\
(4.537)\end{array}$ & - & - \\
\hline$-\mathrm{CO}_{2}$ above & - & - & $\begin{array}{c}4.324 \\
(4.432)\end{array}$ & - \\
\hline RDDBUDGET & $\begin{array}{r}-2.507^{*} \\
(1.043)\end{array}$ & - & - & - \\
\hline POLINVEST & $\begin{array}{c}1.251 \\
(1.274)\end{array}$ & - & - & - \\
\hline POLNETMET & $\begin{array}{c}3.558 \\
(2.102)\end{array}$ & 一 & 一 & 一 \\
\hline POLTEN & $\begin{array}{c}1.540 \\
(3.933)\end{array}$ & - & - & - \\
\hline Cost & $-0.063 * *$ & $-0.049 * *$ & $-0.053 * *$ & $-0.055^{* *}$ \\
\hline GDPcap & $-1.840 * *$ & $-1.690 * *$ & $-1.888 * *$ & $-1.814^{* *}$ \\
\hline GDPcap $^{2}$ & $0.019 * *$ & $0.016^{*}$ & $0.019 * *$ & $0.018^{*}$ \\
\hline OPENNESS & -0.010 & 0.009 & 0.003 & -0.015 \\
\hline POPDENS & 0.034 & 0.050 & 0.046 & 0.052 \\
\hline ENERGYIMPORT & 0.018 & 0.003 & 0.003 & 0.002 \\
\hline ELECCAPACITY & $11.300^{* *}$ & $13.564 * *$ & $11.716^{* *}$ & $10.490 * *$ \\
\hline ELECPRICEHH & $0.040 * *$ & $0.037 * *$ & $0.036^{* *}$ & $0.040^{* *}$ \\
\hline TREND & $-0.702 * *$ & $-0.599 * *$ & $-0.581^{*}$ & $-0.593 *$ \\
\hline Constant & 16.295 & 3.928 & 10.834 & 10.219 \\
\hline Observations & 660 & 660 & 660 & 660 \\
\hline $\mathrm{R}^{2}$ & 0.36 & 0.37 & 0.35 & 0.37 \\
\hline
\end{tabular}

Notes: * Significant at the $5 \%$ level; ** significant at the $1 \%$ level. Standard errors are in parentheses. 
tariff, Low std. dev.), (Low tariff, High std. dev.), (High tariff, Low std. dev.) and (High tariff, High std. dev.). As we have 22 countries with a FIT, we selected the 11 countries with the lowest average tariff for the variable 'low tariff' and the other 11 countries for the variable 'high tariff'. The countries are then sorted at the level of the average standard deviation and are split into 5, 6, 6 and 5 countries, respectively, to construct the four variables. Table 5 shows that only two variables are significant: (Low tariff, Low std. dev.) and (Low tariff, High std. dev.). The coefficients of these two variables have a negative sign. Countries with low tariffs thus have a lower PV added yearly capacity per capita. The effect is much larger when countries have a low tariff and a high standard deviation. As such, for high tariffs, there is no extra effect compared to the effect of the tariff variable. The results of the base model turn out to be robust: coefficients for tariff and its consistency in the base model are not significantly changed. In sum, we do not find evidence that a low, but consistent tariff performs better than a high, but inconsistent tariff. Still, if there is a low tariff, consistency is important.

\section{DISCUSSION AND CONCLUSION}

This paper has empirically analyzed whether or not FIT policies have been effective (in terms of added yearly capacity per capita) in the development of solar PV in OECD member countries in the period 1990-2011. In contrast to the existing literature that analyzes the quantitative effects of FITs, which itself is quite scarce, FIT-structure (tariff, contract duration, presence of a cap, i.e. a maximum on the quantity of installed capacity for which subsidy is available) and policy consistency were explicitly taken into account. We find that the maximum effect of a FIT is much larger if it is well designed. This means that the existing literature, which analyzes only the average effect of applied FITs, underestimates the effectiveness of FITs.

In our base model, we find an average increase of $5.5 \mathrm{Wp}$ installed capacity of solar electricity per inhabitant if a FIT is in place. Compared to the average in our sample of $5.1 \mathrm{Wp}$, this increase is quite substantial. If we discriminate between several design features of the FIT and include consistency in the estimations, we find that the maximum effect can be as much as seven times as large. This maximum effect is achieved with a high tariff and a long contract duration in combination with a consistent policy. Effectiveness decreases in particular when the standard deviation of the tariff and the contract duration increases. This can lead to a negative effect of about $30 \mathrm{Wp}$ per inhabitant. Consistency is especially important when tariffs are low. The combination of a low and inconsistent tariff has a large negative effect on effectiveness. Also, the presence of a cap can decrease effectiveness significantly. If a FIT is combined with a cap, the effect of the FIT decreases by 10.2 watts per inhabitant, on average.

We have strong indications that our results are robust. Our main results are confirmed when we include other policy instruments in the estimation and when we correct for differences between countries with respect to the production of electricity using nuclear or hydro power and $\mathrm{CO}_{2}$-emission levels.

This study is subject to some limitations that provide starting points for further research. First, our results are based on data for only 30 OECD member countries. Data for Australia, Canada, Iceland and the USA were excluded in this paper. This means that conclusions are not necessarily applicable to these countries. We know, for instance, that FITs used in the USA are quite different from the ones used in the 30 OECD member countries in our study. ${ }^{21}$ Further research should be done to see whether or not our conclusions remain valid in the contexts of these other four countries. 
Second, we studied only a sub-sample of the decisive factors influencing the application of solar electricity. From the qualitative literature, we know that other factors such as policy stability, long-term certainty, the availability of disposable income, the permitting and land-access process, the rules and procedures governing grid access and interconnection, net metering and renewable energy targets might be quite important too. We were not able to test the influence of these factors due to the lack of available data.

Third, our study is based on observations up to 2011. After 2011, PV use in small households has become much more popular. Due to significant cost reductions in PV systems, PV has become competitive 'behind the meter' in countries in which net metering policies apply. For example, although the Netherlands also has a flexible feed-in premium system for large-scale PV, its tempestuous growth in recent years has first and foremost been caused by the net-metering policy for small-scale domestic PV and this situation is generally expected to remain unchanged until 2020. Therefore, further research should be done to determine whether or not our conclusions remain valid at present and in the near-future term.

\section{APPENDIX}

\section{Table A.1: List of Variables}

\begin{tabular}{|c|c|c|c|}
\hline Variable name & Definition & Unit & Source \\
\hline ADDCAPC & $\begin{array}{l}\text { Installed new capacity for PV per } \\
\text { capita in this year }\end{array}$ & Wp per capita & OECD-iLibrary \\
\hline FIT (dummy) & $\begin{array}{l}1 \text { if in a country in a year a FIT } \\
\text { exists and } 0 \text { otherwise }\end{array}$ & Dummy & $\begin{array}{l}\text { Composed using all data sources } \\
\text { Table A. } 2\end{array}$ \\
\hline Tariff & Feed-in tariff in US\$ per MWh & US\$/MWh & $\begin{array}{l}\text { Composed using all data sources } \\
\text { Table A. } 2\end{array}$ \\
\hline -Std. dev. & $\begin{array}{l}\text { Standard deviation of the last five } \\
\text { observations of Tariff }\end{array}$ & US\$/MWh & Authors' own calculations \\
\hline —Nuclear/Hydro & $\begin{array}{l}\text { Tariff times dummy that is } 1 \text { for } \\
\text { countries with higher than } \\
\text { average share of nuclear or } \\
\text { hydro sources in the electricity } \\
\text { generation mix in } 2011 \text { and } 0 \\
\text { otherwise }\end{array}$ & US\$/MWh & $\begin{array}{l}\text { Authors' own calculations based } \\
\text { on data for electricity } \\
\text { production from OECD- } \\
\text { iLibrary }\end{array}$ \\
\hline$-\mathrm{CO}_{2}$ above & $\begin{array}{l}\text { Tariff times dummy that is } 1 \text { if in } \\
\text { a country the } \mathrm{CO}_{2} \text { emissions } \\
\text { per capita in } 2011 \text { were above } \\
\text { the average for all countries in } \\
\text { the sample and } 0 \text { otherwise }\end{array}$ & US\$/MWh & $\begin{array}{l}\text { Authors' own calculations based } \\
\text { on data for } \mathrm{CO}_{2} \text { from OECD- } \\
\text { iLibrary }\end{array}$ \\
\hline $\begin{array}{l}\text { —Low tariff, Low } \\
\text { std. dev. }\end{array}$ & $\begin{array}{l}1 \text { for } 5 \text { countries with lowest level } \\
\text { of standard deviation, on } \\
\text { average, for the } 11 \text { countries } \\
\text { with lowest average level of } \\
\text { Tariff and } 0 \text { otherwise }\end{array}$ & Dummy & Authors' own calculations \\
\hline $\begin{array}{l}\text { —Low tariff, High } \\
\text { std. dev. }\end{array}$ & $\begin{array}{l}1 \text { for } 5 \text { countries with highest } \\
\text { level of standard deviation, on } \\
\text { average, for the } 11 \text { countries } \\
\text { with lowest average level of } \\
\text { Tariff and } 0 \text { otherwise }\end{array}$ & Dummy & Authors' own calculations \\
\hline $\begin{array}{l}\text { — High tariff, Low } \\
\text { std. dev. }\end{array}$ & $\begin{array}{l}1 \text { for } 5 \text { countries with lowest level } \\
\text { of standard deviation, on } \\
\text { average, for the } 11 \text { countries } \\
\text { with highest average level of } \\
\text { Tariff and } 0 \text { otherwise }\end{array}$ & Dummy & Authors' own calculations \\
\hline
\end{tabular}


Table A.1: List of Variables (continued)

\begin{tabular}{|c|c|c|c|}
\hline Variable name & Definition & Unit & Source \\
\hline $\begin{array}{l}\text { — High tariff, High } \\
\text { std. dev. }\end{array}$ & $\begin{array}{l}1 \text { for } 5 \text { countries with highest } \\
\text { level of standard deviation, on } \\
\text { average, for the } 11 \text { countries } \\
\text { with highest average level of } \\
\text { Tariff and } 0 \text { otherwise }\end{array}$ & Dummy & Authors' own calculations \\
\hline Duration & $\begin{array}{l}\text { Number of years for which FIT is } \\
\text { defined in contract }\end{array}$ & Years & $\begin{array}{l}\text { Composed using all data sources } \\
\text { Table A. } 2\end{array}$ \\
\hline —Std. dev. & $\begin{array}{l}\text { Standard deviation of the last five } \\
\text { observations of Tariff }\end{array}$ & Years & Authors' own calculations \\
\hline —Nuclear/Hydro & $\begin{array}{l}\text { Duration times dummy that is } 1 \\
\text { for countries with higher than } \\
\text { average share of nuclear or } \\
\text { hydro sources in the electricity } \\
\text { generation mix in } 2011 \text { and } 0 \\
\text { otherwise }\end{array}$ & Years & $\begin{array}{l}\text { Authors' own calculations based } \\
\text { on data for electricity } \\
\text { production from OECD- } \\
\text { iLibrary }\end{array}$ \\
\hline$-\mathrm{CO}_{2}$ above & $\begin{array}{l}\text { Duration times dummy that is } 1 \text { if } \\
\text { in a country the } \mathrm{CO}_{2} \text { emissions } \\
\text { per capita in } 2011 \text { were above } \\
\text { the average for all countries in } \\
\text { the sample and } 0 \text { otherwise }\end{array}$ & Years & $\begin{array}{l}\text { Authors' own calculations based } \\
\text { on data for } \mathrm{CO}_{2} \text { from OECD- } \\
\text { iLibrary }\end{array}$ \\
\hline Cap (dummy) & $\begin{array}{l}1 \text { if budget or installed capacity is } \\
\text { capped and } 0 \text { otherwise }\end{array}$ & Dummy & $\begin{array}{l}\text { Composed using all data sources } \\
\text { Table A. } 2\end{array}$ \\
\hline -Std. dev. & $\begin{array}{l}\text { Standard deviation of the last five } \\
\text { observations of Tariff }\end{array}$ & Dummy & Authors' own calculations \\
\hline —Nuclear/Hydro & $\begin{array}{l}\text { Cap (dummy) times dummy that } \\
\text { is } 1 \text { for countries with higher } \\
\text { than average share of nuclear or } \\
\text { hydro sources in the electricity } \\
\text { generation mix in } 2011 \text { and } 0 \\
\text { otherwise }\end{array}$ & Dummy & $\begin{array}{l}\text { Authors' own calculations based } \\
\text { on data for electricity } \\
\text { production from OECD- } \\
\text { iLibrary }\end{array}$ \\
\hline$-\mathrm{CO}_{2}$ above & $\begin{array}{l}\text { Cap (dummy) times dummy that } \\
\text { is } 1 \text { if in a country the } \mathrm{CO}_{2} \\
\text { emissions per capita in } 2011 \\
\text { were above the average for all } \\
\text { countries in the sample and } 0 \\
\text { otherwise }\end{array}$ & Dummy & $\begin{array}{l}\text { Authors' own calculations based } \\
\text { on data for } \mathrm{CO}_{2} \text { from OECD- } \\
\text { iLibrary }\end{array}$ \\
\hline RDDBUDGET & $\begin{array}{l}\text { Government investment in PV } \\
\text { Research }\end{array}$ & $\begin{array}{l}\text { US\$ per capita } \\
\text { (2010 prices } \\
\text { + exchange rates) }\end{array}$ & IEA RD\&D Database \\
\hline POLINVEST & $\begin{array}{l}\text { Binary for presence of investment/ } \\
\text { tax policies }\end{array}$ & Binary $0 / 1$ & $\begin{array}{l}\text { IEA/IRENA Global Renewable } \\
\text { Energy Policies and Measures } \\
\text { Database } \\
\text { EPIA's Global Market Outlook } \\
2013 \\
\text { PV-Tech } \\
\text { Wind-works.org }\end{array}$ \\
\hline POLNETMET & $\begin{array}{l}\text { Binary for presence of net } \\
\text { metering policies }\end{array}$ & Binary $0 / 1$ & $\begin{array}{l}\text { IEA/IRENA Global Renewable } \\
\text { Energy Policies and Measures } \\
\text { Database } \\
\text { EPIA's Global Market Outlook } \\
2013 \\
\text { PV-Tech } \\
\text { Wind-works.org }\end{array}$ \\
\hline
\end{tabular}


Table A.1: List of Variables (continued)

\begin{tabular}{|c|c|c|c|}
\hline Variable name & Definition & Unit & Source \\
\hline POLTEN & $\begin{array}{l}\text { Binary for presence of tender } \\
\text { policies }\end{array}$ & Binary $0 / 1$ & $\begin{array}{l}\text { IEA/IRENA Global Renewable } \\
\text { Energy Policies and Measures } \\
\text { Database } \\
\text { EPIA's Global Market Outlook } \\
2013 \\
\text { PV-Tech } \\
\text { Wind-works.org }\end{array}$ \\
\hline COST & $\begin{array}{l}\text { System costs in US\$ per MWh } \\
\text { corrected for solar irradation }\end{array}$ & US\$/MWh & $\begin{array}{l}\text { Composed using all data sources } \\
\text { Table A. } 2\end{array}$ \\
\hline GDPcap & GDP per capita & $\begin{array}{c}\text { US\$ (in constant } \\
\text { prices of 2000) } \\
\text { per inhabitant }\end{array}$ & The World Bank \\
\hline OPENNESS & $\begin{array}{l}\text { Exports plus imports as share of } \\
\text { GDP }\end{array}$ & $\%$ & The World Bank \\
\hline POPDENS & Population density & Capita per sq. km & The World Bank \\
\hline ENERGYIMPORT & Share of imports in energy use & $\%$ & OECD-iLibrary \\
\hline ELECCAPACITY & Electricity generation capacity & MWe per capita & OECD-iLibrary \\
\hline ELECPRICEHH & Electricity price households & US\$ per MWhe & OECD-iLibrary \\
\hline
\end{tabular}

Table A.2: Internet Address Data Sources

\begin{tabular}{|c|c|}
\hline Data source & Location \\
\hline A-E-S Europe GmbH & $\begin{array}{l}\text { http://www.europe-solar.de/catalog/index.php?main_page }=\text { page } \& \text { id }=34 \& \\
\text { chapter }=0\end{array}$ \\
\hline EPIA’s Global Market Outlook 2013 & http://ec.europa.eu/economy_finance/events/2009/20091120/epia_en.pdf \\
\hline Europe's Energy Portal & http://www.energy.eu/ \\
\hline European Commission DG Energy & http://ec.europa.eu/energy/ \\
\hline IEA Policies \& Measures Databases & http://www.iea.org/policiesandmeasures/ \\
\hline $\begin{array}{l}\text { IEA/IRENA Global Renewable Energy } \\
\text { Policies and Measures Database }\end{array}$ & http://www.iea.org/policiesandmeasures/renewableenergy/ \\
\hline IEA RD\&D Database & http://www.iea.org/statistics/RDDonlinedataservice/ \\
\hline $\begin{array}{l}\text { IEA's Renewable Energy Market \& } \\
\text { Policy Trends in IEA Countries }\end{array}$ & $\begin{array}{l}\text { http://s3.amazonaws.com/zanran_storage/www.iea.org/ContentPages/ } \\
\text { 9895294.pdf }\end{array}$ \\
\hline OECD-iLibrary & http://www.oecd-ilibrary.org/statistics/ \\
\hline PV GRID & http://www.pvgrid.eu/database.html \\
\hline PV LEGAL & http://www.pvlegal.eu/nc/en/database.html \\
\hline PV-Tech & http://www.pv-tech.org/ \\
\hline RES LEGAL & http://www.res-legal.eu/compare-support-schemes/ \\
\hline The World Bank & http://data.worldbank.org/ \\
\hline Wikipedia & http://en.wikipedia.org/wiki/Feed-in_tariff \\
\hline Wind-works.org & http://www.wind-works.org/cms/index.php?id $=92$ \\
\hline
\end{tabular}

\section{ACKNOWLEDGMENTS}

The authors are grateful to four anonymous referees for their very thoughtful comments on earlier versions of this paper.

\section{REFERENCES}

Alizamir, Saed, Francis de Véricourt, and Peng Sun (2016). "Efficient Feed-In-Tariff Policies for Renewable Energy Technologies." Operations Research 64(1): 52-66. http://dx.doi.org/10.1287/opre.2015.1460.

Bolkesjø, Torjus F., Petter T. Eltvig, and Erik Nygaard (2014). "An Econometric Analysis of Support Scheme Effects on Renewable Energy Investments in Europe.” Energy Procedia 58: 2-8. http://dx.doi.org/10.1016/j.egypro.2014.10.401. 
Bürer, Mary J. and Rolf Wüstenhagen (2009). "Which Renewable Energy Policy is a Venture Capitalist's Best Friend? Empirical Evidence from a Survey of International Cleantech Investors.” Energy Policy 37(12): 4997-5006. http:// dx.doi.org/10.1016/j.enpol.2009.06.071.

Cory, Karlynn, Toby Couture, and Claire Kreycik (2009). "Feed-in Tariff Policy: Design, Implementation, and RPS Policy Interactions." National Renewable Energy Laboratory, NREL/TP-6A2-45549, March. Available at http://www.nrel.gov/ docs/fy09osti/45549.pdf.

Couture, Toby D., Karlynn Cory, Claire Kreycik, and Emily Williams (2010). “A Policymaker's Guide to Feed-in Tariff Policy Design.” National Renewable Energy Laboratory, NREL/TP-6A2-44849, July. Available at http://www.nrel.gov/ docs/fy10osti/44849.pdf.

Couture, Toby and Yves Gagnon (2010). “An Analysis of Feed-in Tariff Remuneration Models: Implications for Renewable Energy Investment.” Energy Policy 38(2): 955-965. http://dx.doi.org/10.1016/j.enpol.2009.10.047.

DeShazo, J.R. and Ryan Matulka (2009). "Designing an Effective Feed-in Tariff for Greater Los Angeles." Los Angeles Business Council \& UCLA Luskin Center for Innovation. Available at http://www.labusinesscouncil.org/files/Reports/ Designing-an-Effective-Feed-in-Tariff-for-Greater-Los-Angeles-040110.pdf.

EPIA (2013). Global Market Outlook for Photovoltaics until 2013. Available at http://ec.europa.eu/economy_finance/events/ 2009/20091120/epia_en.pdf.

Gardner, Gerald T. and Paul C. Stern (1996). Environmental Problems and Human Behavior. Boston: Allyn and Bacon.

Gipe, Paul (2006). "Renewable Energy Policy Mechanisms.” February 17. Available at http://www.wind-works.org/cms/ fileadmin/user_upload/RenewableEnergyPolicyMechanismsbyPaulGipe.pdf.

Grau, Thilo (2014). "Comparison of Feed-in Tariffs and Tenders to Remunerate Solar Power Generation." DIW Berlin Discussion Paper 1363. Available at http://www.diw.de/documents/publikationen/73/diw_01.c.437464.de/dp1363.pdf.

Green, Richard and Adonis Yatchew (2012). "Support Schemes for Renewable Energy: An Economic Analysis." Economics of Energy \& Environmental Policy 1(2): 83-98. http://dx.doi.org/10.5547/2160-5890.1.2.6.

Grossman, Gene M. and Alan B. Krueger (1993). "Environmental Impacts of a North American Free Trade Agreement." In: Garber, Peter M., ed., The Mexico-U.S. Free Trade Agreement. Cambridge, MA: The MIT Press.

Haas, Reinhard, Gustav Resch, Christian Panzer, Sebastian Busch, Mario Ragwitz, and Anne Held (2011a). "Efficiency and Effectiveness of Promotion Systems for Electricity Generation from Renewable Energy Sources—Lessons from EU Countries.” Energy 36(4): 2186-2193. http://dx.doi.org/10.1016/j.energy.2010.06.028.

Haas, Reinhard, Christian Panzer, Gustav Resch, Mario Ragwitz, Gemma Reece, and Anne Held (2011b). “A Historical Review of Promotion Strategies for Electricity from Renewable Energy Sources in EU Countries." Renewable and Sustainable Energy Reviews 15(2): 1003-1034. http://dx.doi.org/10.1016/j.rser.2010.11.015.

IEA (2004). Renewable Energy. Market \& Policy Trends in IEA Countries. Available at http://s3.amazonaws.com/zanran_storage/www.iea.org/ContentPages/9895294.pdf.

Jenner, Steffen (2012). "Did Feed-in Tariffs Work? An Econometric Assessment." Available at http://ssrn.com/abstract $=2121261$.

Jenner, Steffen, Gabriel Chan, Rolf Frankenberger, and Mathias Gabel (2012). "What Drives States to Support Renewable Energy?" The Energy Journal 33(2): 1-12. http://dx.doi.org/10.5547/01956574.33.2.1.

Jenner, Steffen, Felix Groba, and Joe Indvik (2013). "Assessing the Strength and Effectiveness of Renewable Electricity Feed-in Tariffs in European Union Countries.” Energy Policy 52: 385-401. http://dx.doi.org/10.1016/j.enpol.2012.09.046.

Klein, Arne, Erik Merkel, Benjamin Pfluger, Anne Held, Mario Ragwitz, Gustav Resch, and Sebastian Busch (2010). "Evaluation of Different Feed-in Tariff Design Options-Best Practice Paper for the International Feed-in Cooperation." Fraunhofer ISI \& Energy Economics Group. Available at http://www.feed-in-cooperation.org/wDefault_7/download-files/ research/Best_practice_Paper_3rd_edition.pdf.

Loiter, Jeffrey M. and Vicki Norberg-Bohm (1999). “Technology Policy and Renewable Energy: Public Roles in the Development of New Energy Technologies.” Energy Policy 27(2): 85-97. http://dx.doi.org/10.1016/S0301-4215(99)000130 .

Lüthi, Sonja (2010). "Effective Deployment of Photovoltaics in the Mediterranean Countries: Balancing Policy Risk and Return.” Solar Energy 84(6): 1059-1071. http://dx.doi.org/10.1016/j.solener.2010.03.014.

Lüthi, Sonja and Rolf Wüstenhagen (2012). "The Price of Policy Risk-Empirical Insights from Choice Experiments with European Photovoltaic Project Developers." Energy Economics 34(4): 1001-1011. http://dx.doi.org/10.1016/ j.eneco.2011.08.007.

Marques, António C., José A. Fuinhas, and J.R. Pires Manso (2010). "Motivations Driving Renewable Energy in European Countries: A Panel Data Approach.” Energy Policy 38(11): 6877-6885. http://dx.doi.org/10.1016/j.enpol.2010.07.003.

Marques, António C. and José A. Fuinhas (2012). “Are Public Policies towards Renewables Successful? Evidence from European Countries.” Renewable Energy 44: 109-118. http://dx.doi.org/10.1016/j.renene.2012.01.007.

Copyright (C) 2018 by the IAEE. All rights reserved. 
Menanteau, Philippe, Dominique Finon, and Marie-Laure Lamy (2003). "Prices versus Quantities: Choosing Policies for Promoting the Development of Renewable Energy." Energy Policy 31(8): 799-812. http://dx.doi.org/10.1016/S03014215(02)00133-7.

Mendonça, Miguel (2007). Feed-in Tariffs: Accelerating the Deployment of Renewable Energy. London: Earthscan.

Mendonça, Miguel, David Jacobs, and Benjamin K. Sovacool (2009). Powering the Green Economy: The Feed-in Tariff Handbook. London: Earthscan.

MIT Energy Initiative (2015). The Future of Solar Energy. An Interdisciplinary MIT Study. Available at http://mitei.mit.edu/ futureofsolar.

Owens, Susan and Louise Driffill (2008). "How to Change Attitudes and Behaviours in the Context of Energy." Energy Policy 36(12): 4412-4418. http://dx.doi.org/10.1016/j.enpol.2008.09.031.

Panayotou, Theodore (1993). "Empirical Tests and Policy Analysis of Environmental Degradation at Different Stages of Economic Development.” Working Paper WP238, Technology and Employment Programme (World Employment Programme Research), January. Geneva: International Labour Office. Available at http://www.ilo.org/public/libdoc/ilo/1993/ 93B09_31_engl.pdf.

REN21 (2016). Renewables 2016 Global Status Report. Paris: REN21 Secretariat. Available at http://www.ren21.net/wpcontent/uploads/2016/05/GSR_2016_Full_Report_lowres.pdf.

Resch, Gustav, Mario Ragwitz, Anne Held, Thomas Faber, and Reinhard Haas (2007). "Feed-in Tariffs and Quotas for Renewable Energy in Europe." CESifo DICE Report 4/2007: 26-32. Available at http://www.cesifo-group.de/DocDL/ dicereport407-forum5.pdf.

Schmalensee, Richard (2012). "Evaluating Policies to Increase Electricity Generation from Renewable Energy." Review of Environmental Economics and Policy 6(1): 45-64. http://dx.doi.org/10.1093/reep/rer020.

Shrimali, Gireesh, Gabriel Chan, Steffen Jenner, Felix Groba, and Joe Indvik (2015). "Evaluating Renewable Portfolio Standards for In-State Renewable Deployment: Accounting for Policy Heterogeneity." Economics of Energy \& Environmental Policy 4(2): 127-142. http://dx.doi.org/10.5547/2160-5890.4.2.gshr.

Timilsina, Govinda R., Lado Kurdgelashvili, and Patrick A. Narbel (2012). "Solar Energy: Markets, Economics and Policies.” Renewable and Sustainable Energy Reviews 16(1): 449-465. http://dx.doi.org/10.1016/j.rser.2011.08.009.

Van Rooijen, Sascha N.M. and Mark T. van Wees (2006). "Green Electricity Policies in the Netherlands: An Analysis of Policy Decisions.” Energy Policy 34(1): 60-71. http://dx.doi.org/10.1016/j.enpol.2004.06.002.

White, William, Anders Lunnan, Erlend Nybakk, and Biljana Kulisic (2013). "The Role of Governments in Renewable Energy: The Importance of Policy Consistency.” Biomass and Bioenergy 57: 97-105. http://dx.doi.org/10.1016/ j.biombioe.2012.12.035.

Zhang, Fan (2013). "How Fit are Feed-in Tariff Policies? Evidence from the European Wind Market." Policy Research Working Paper 6376, The World Bank, February. http://dx.doi.org/10.1596/1813-9450-6376. 


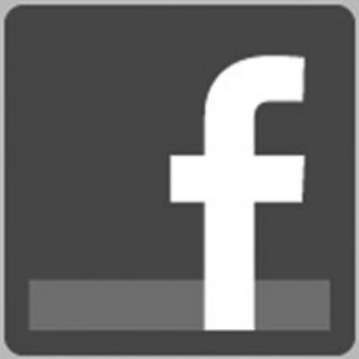

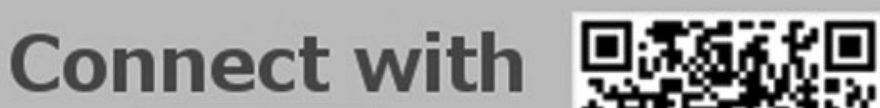

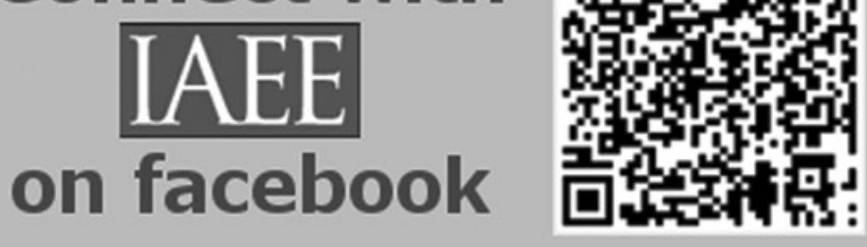

